\title{
Neuroinflammation in the pathophysiology of Parkinson's disease and therapeutic evidence of anti-inflammatory drugs
}

\author{
Neuroinflamação na patofisiologia da doença de Parkinson e evidências terapêuticas de \\ drogas antiinflamatórias
}

Taysa Bervian Bassani',2, Maria A.B.F. Vital², Laryssa K. Rauh ${ }^{1}$

\begin{abstract}
Parkinson's disease (PD) is the second most common neurodegenerative disease affecting approximately $1.6 \%$ of the population over 60 years old. The cardinal motor symptoms are the result of progressive degeneration of substantia nigra pars compacta dopaminergic neurons which are involved in the fine motor control. Currently, there is no cure for this pathology and the cause of the neurodegeneration remains unknown. Several studies suggest the involvement of neuroinflammation in the pathophysiology of PD as well as a protective effect of anti-inflammatory drugs both in animal models and epidemiological studies, although there are controversial reports. In this review, we address evidences of involvement of inflammatory process and possible therapeutic usefulness of anti-inflammatory drugs in PD.
\end{abstract}

Keywords: Parkinson's disease, neuroinflammation, anti-inflammatory.

\section{RESUMO}

A doença de Parkinson (DP) é a segunda doença neurodegenerativa mais comum afetando aproximadamente 1,6\% da população acima de 60 anos de idade. Os sinais motores cardinais são o resultado da degeneração progressiva de neurônios dopaminérgicos da substantia nigra pars compacta (SNpc), a qual está intimamente envolvida com o controle motor. Atualmente, não há cura para esta patologia e a causa da neurodegeneração permanece desconhecida. Contudo, muitos estudos sugerem o envolvimento da neuroinflamação na patofisiologia da DP bem como um efeito protetor de drogas antiinflamatórias tanto em modelos animais quanto em estudos epidemiológicos, embora haja relatos controversos. Nesta revisão, foram abordadas evidências de envolvimento do processo inflamatório e uma possível utilidade terapêutica de drogas antiinflamatórias na DP.

Palavras-chave: doença de Parkinson, neuroinflamação, antiinflamatórios.

Parkinson's disease (PD) is the second most common neurodegenerative disease affecting $1.6 \%$ of people over 60 years old $^{1,2}$. PD is also the most common cause of parkinsonism, corresponding to $74.7 \%$ of all cases in a Brazilian study ${ }^{3}$. The disease is characterized by the progressive degeneration of dopaminergic neurons in the substantia nigra pars compacta (SNpc), loss of their ascending projections to the striatum (caudate and putamen), and consequent decrease of striatal dopamine (DA) content, which leads to severe locomotion difficulties and cardinal motor symptoms such as tremor at rest, rigidity, postural instability and slowness of body movements (bradykinesia) ${ }^{4,5}$. By the time a patient is diagnosed, approximately $60 \%$ of SNpc neurons are degenerated and
$80 \%$ of striatal DA content is depleted ${ }^{4,5}$. In addition to neuronal damage, PD is characterized by the presence of proteinaceous inclusions called Lewy bodies and Lewy neurites, mainly in the SNpc ${ }^{6}$.

Currently, the pharmacological and non-pharmacological treatments approved for PD offer only symptomatic relief for patients. As these treatments are not able to stop or reverse the neurodegenerative process, PD remains incurable. The motor symptoms can be reduced by many drugs that increase the DA level in the central nervous system (CNS) or mimic its effects. The gold standard for the treatment of PD nowadays is Levodopa, a DA precursor. Other drugs commonly prescribed are DA receptor agonists, monoaminoxidase (MAO)

1Pontifícia Universidade Católica do Paraná, Curitiba PR, Brazil;

Universidade Federal do Paraná, Departamento de Farmacologia, Curitiba PR, Brazil.

Correspondence: Taysa Bervian Bassani; Departamento de Farmacologia, UFPR; Rua Cel. Francisco H. dos Santos, 100; Centro Politécnico, Jardim das Américas; Caixa Postal 19031; 81531-980 Curitiba,PR, Brasil; E-mail: taysa_bassani@yahoo.com.br

Conflict of interest: There is no conflict of interest to declare.

Support: Capes, CNPq.

Received 04 October 2014; Received in final form 10 February 2015; Accepted 03 March 2015. 
inhibitors (such as selegiline and rasagiline), amantadine, cathecol-o-methyl-transferase (COMT) inhibitors and anticholinergic agents ${ }^{7}$.

The origin of neuronal degeneration in PD is still unclear but it is known that several cellular and molecular events are involved, including aging, oxidative stress, protein aggregates, excitotoxicity, mitochondrial and proteassomal disfunction, apoptose and environmental toxins ${ }^{8,9}$. Recently, it has been suggested that neuroinflammatory mechanisms contribute to the cascade of events which leads to the neuronal degeneration. Neuroinflammation can be a consequence of neurodegeneration; however, some lines of evidence suggest that inflammation can be also involved in the process of neuronal death ${ }^{6}$. This review presents significant evidence of neuroinflammation in the pathophysiology of PD and highlights the potential role of anti-inflammatory drugs in the prevention and treatment of this disease.

\section{EVIDENCE OF NEUROINFLAMMATION IN PARKINSON'S DISEASE}

Post-mortem, epidemiological and imaging studies from patients, and also studies with animal models have highlighted the role of neuroinflammation in PD and raised the interesting possibility that chronic inflammation may act as a stressor environment that promotes the progressive degeneration of dopaminergic neurons ${ }^{10}$.

In 1998, Mc Geer et al. ${ }^{11}$ provided one of the first evidence of inflammation in PD by showing there was infiltration of T-lymphocytes in the SNpc of a patient with PD. Later, Brochard et al. ${ }^{12}$ demonstrated the presence of infiltrates of $\mathrm{CD}^{+}$and $\mathrm{CD}^{+}{ }^{+}$T-lymphocytes in the substantia nigra (SN) of PDpatientsand 1-methyl-4-phenyl-1,2,3,6-tetrahydropyridine (MPTP)-treated mice. The specific antigens that trigger the adaptive immune response and lymphocytic infiltration have not been identified but likely include oxidatively-modified $\alpha$-synuclein, particularly the nitrated form, released from dying neurons ${ }^{13,14}$.

Activation of microglia, the resident immune cells of the CNS, has been evidenced in post-mortem brains of PD patients, mainly in the SN and putamen, the most affected areas in this disease, but also in hippocampus and many cortical areas such as transentorhinal, cingulate and temporal cortices, where neuronal loss is also important ${ }^{5,15,16}$. Microglia can be activated by molecules released by dying dopaminergic neurons such as $\alpha$-synuclein aggregates, ATP, matrix metalloproteinase-3 (MMP-3) and neuromelanin. Lipopolysaccharide (LPS) also activates microglia both in vitro and in vivo ${ }^{5}$.

Several studies support the hypothesis that activation of the

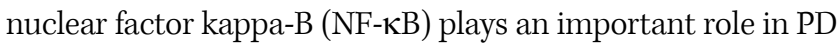
pathogenesis. Ghosh et al. ${ }^{17}$ have shown that NF- $\kappa \mathrm{B}$ activation is induced in the SNpc of patients with PD and MPTP-treated mice. On the other hand, the selective inhibition of NF- $\kappa \mathrm{B}$ protected dopaminergic neurons from the MPTP toxicity ${ }^{17}$. In the hemiparkinsonian monkey model of PD, it was also demonstrated that NF- $\mathrm{KB}$ is activated in the SNpc of these animals and inhibition of NF- $\kappa$ B resulted in suppression of proinflammatory molecules, protection of SNpc dopaminergic neurons and improvement in locomotor activity ${ }^{18}$.

When NF- $\kappa \mathrm{B}$ is activated, it enters the nucleus and stimulates the gene transcription of several proinflammatory factors including inducible nitric oxide synthase (iNOS), interleukin (IL)-1 $\beta$, IL-6, cyclooxigenase 2 (COX-2) and tumor necrosis factor- $\alpha$ (TNF- $\alpha$ by the microglia ${ }^{19,20}$. Probably because of this, the proinflammatory cytokines IL- $1 \beta$, TNF- $\alpha$, IL-2 and IL-6 are expressed at higher levels in PD post-mortem brains as well as in cerebrospinal fluid (CSF) and serum of PD patients, compared with age-matched controls ${ }^{5}$. In addition, the inflammatory process associated with an increase in COX-2 expression and elevated concentrations of prostaglandin E2 (PGE2) have been implicated in the deleterious events that leads to neuronal degeneration in $\mathrm{PD}^{21}$. COX-2 aggravates the degenerative process through proinflammatory mechanisms and generation of reactive oxygen species (ROS). The expression of COX-2 is induced specifically in the SNpc of patients with PD and in animal models induced by MPTP, LPS and 6-hydroxydopamine (6-OHDA) ${ }^{21}$.

Besides COX-2, isoforms of the NOS enzyme also participate in dopaminergic neurodegeneration. Mice treated with MPTP have shown increased levels of iNOS in the SN. Consistently, mice deficient in iNOS were more resistant then the wild type to MPTP-induced dopaminergic loss ${ }^{22}$. Nitric oxide (NO) generated by NOS may react with ROS to form highly toxic reactive nitrogen species (RNS), which are deleterious to neurons. The supranigral injection of LPS in rats resulted in iNOS overexpression and production of NO leading to the loss of dopaminergic neurons and this effect was blocked by NOS inhibitors ${ }^{22}$.

Environmental factors known to promote neuroinflammatory response have been related to idiopathic PD. Neuroinflammation can be triggered by immunological challenges (viral or bacterial infections), neuronal injury (brain trauma or stroke) and other epigenetic factors including chronic inflammatory syndromes (arthritis, atherosclerosis, Crohn's disease and multiple sclerosis) and environmental toxins such as MPTP, paraquat, rotenone, particulate material, heavy metals and organophophorate compounds ${ }^{23}$. In addition, there are several epidemiological reports which correlate the incidence of secondary parkinsonism with systemic inflammatory events such as viral infections caused by influenza A-H1N1, influenza A-H5N1, coxsackie, St. Louis, west Nile and human immunodeficiency viruses (HIV) and Japanese-encephalitis $\mathrm{B}^{24}$. These peripheral insults may cause the increase in blood brain barrier permeability which could allow the infiltration of lymphocytes and macrophages in brain parenquima ${ }^{10}$. 


\section{THERAPEUTIC EVIDENCE OF ANTI-INFLAMMATORY} DRUGS IN PARKINSON'S DISEASE

\section{Preclinical studies (in vivo and in vitro)}

Glucocorticoids are potent anti-inflammatory drugs that have been used in clinical practice for the treatment of inflammatory conditions including brain inflammation and lesions in the spinal cord. Glucocorticoids are known to have numerous effects on the cellular lineage of macrophages/microglia. They are potent inhibitors of IFN (interferon)- $\gamma$-induced microglial activation in vitro and they negatively regulate the expression of the Major Histocompatibility Complex (MHC) class II in macrophages, both in vitro and in vivo. Dexamethasone, a member of the glucocorticoid class, inhibits the induction of COX-2 mRNA and the consequent production of prostaglandins. It also negatively regulates the expression of MHC class II induced by IFN- $\gamma$ in microglia of rats and reversibly inhibits microglial proliferation in vitro. In an animal model of dopaminergic degeneration induced by intranigral injection of LPS, a potent inductor of inflammation, dexamethasone prevented the catecholamine depletion, the reduction in the activity and expression of tyrosine hydroxylase (limiting enzyme in dopamine synthesis) and also inhibits activation of microglia ${ }^{25}$.

In the model of a nigrostriatal lesion induced by systemic injections of MPTP in mice, dexamethasone reduced the MPTP-induced striatal DA depletion, the loss of nigral dopaminergic cells and the inflammatory reaction (glial activation and lymphocitary infiltration) in damaged $\operatorname{areas}^{26}$. The neuroprotective effect of dexamethasone was also observed when LPS was intranigraly injected in wistar rats which were previously exposed to 6-OHDA. LPS exacerbated the neurodegeneration, accelerated and increased motor signs, and changed microglia to a proinflammatory phenotype with increased secretion of IL-1 $\beta$ Exacerbation of neurodegeneration and motor signs were inhibited by dexamethasone and IL-1 inhibitors ${ }^{27}$. Despite the neuroprotective effects of dexamethasone in several preclinical studies, some authors point that the severe side effects associated with the prolonged use of glucocorticoids make them unfeasible as neuroprotective therapy in patients with $\mathrm{PD}^{5,24}$.

The involvement of the inflammatory process in the pathophysiology of PD is also supported by reports from animal models, because the neurotoxin-induced degeneration of nigral dopaminergic neurons can be prevented by some non-steroidal anti-inflammatory drugs (NSAIDs). They are commonly used in clinical practice because of their analgesic, antipyretic and anti-inflammatory properties. NSAIDs have heterogeneous pharmacological properties based on the inhibition of COX, and in many other known and unknown mechanisms not shared by all members of this class ${ }^{28}$. Several preclinical studies in vitro and in vivo have demonstrated that pre-treatment with NSAIDs protects dopaminergic neurons of SN from degeneration induced by MPTP and 6-OHDA (reviewed by Esposito et al. ${ }^{29}$ ).

When activated by LPS, microglia increases the expression of COX-2 and, consequently, the synthesis of prostaglandins related to the inflammatory process. Prostaglandins can be directly toxic to neurons through the activation of caspase-3 or indirectly through the release of glutamate by astrocytes, leading to excitotoxicity. The COX-2 depletion in mice resulted in protection against the MPTP-induced loss of nigral dopaminergic neurons ${ }^{22}$. Moreover, the selective inhibition of COX-2 prevented microglial activation and loss of nigral dopaminergic neurons induced by MPTP and 6-OHDA. This data suggests therapeutic efficacy of COX-2 inhibitors against the neurodegeneration ${ }^{28,30}$.

Some NSAIDs also have antioxidant properties due to their ability to scavenge free radicals and/or to reduce their production. In the CNS, the production of nitric oxide radical (NO) induced by LPS and/or inflammatory cytokines is reduced by acetylsalicylic acid, sodium salicylate and indomethacin in therapeutic concentrations. This effect is caused by inhibition of NF-KB activation and iNOS mRNA expression, which consequently reduces NO production. In addition, acetylsalicylic acid, mefenamic acid, indomethacin ketoprofen and ibuprofen can directly, and dose-dependently scavenge $\mathrm{NO}$ at clinically relevant concentrations ${ }^{28}$. Ibuprofen, in particular, has recently shown neuroprotective effects in a rotenone model of PD, due to the increase in the glutathione levels in striatum and hippocampus, and the increase in catalase activity ${ }^{31}$. Besides the rotenone model, ibuprofen also prevented dopaminergic degeneration in the MPTP mice model ${ }^{32}$. NSAIDs are potent ROS and RNS scavengers and some of them such as ibuprofen, indomethacin and naproxen exert neuroprotective effects both in vitro and in vivo as ligands of the anti-inflammatory peroxisome proliferator-activated receptor $\gamma(\operatorname{PPAR} \gamma)^{6,28}$.

The PPAR $\gamma$ receptor has shown anti-inflammatory activity in the periphery and in the CNS, where it is localized at glia and neurons. When this receptor is activated by its natural ligands eicosanoids and prostaglandin J2, it reduces the expression of proinflammatory factors such as NF- $\mathrm{kB}$, iNOS, COX-2 and a broad spectrum of cytokines. Other drugs such as pioglitazone and rosiglitazone, both synthetic agonists of the PPAR $\gamma$ receptor approved for the treatment of type 2 diabetes, exhibit neuroprotective effect in models of neurodegenerative diseases, including PD, by preventing inflammation, oxidative damage and apoptosis ${ }^{24,33}$.

As mentioned above, NSAIDs seem to exert their neuroprotective actions not only by inhibiting COX activity, and consequently, prostaglandins production; but also by the activation of PPAR $\gamma$ receptor, inactivation of NF- $\mathrm{BB}$, suppression of iNOS mRNA transcription, direct scavenging of ROS and RNS, and probably by other unknown mechanisms. Recently, it has been proposed that anti-inflammatory drugs may suppress microglial proliferation by modulating cell 
cycle and apoptosis. This variety of targets provides heterogeneous pharmacological properties for NSAIDs ${ }^{29}$.

\section{Epidemiological studies on the regular use of NSAIDs and the risk of developing Parkinson's disease}

Epidemiological studies that attempted to correlate the regular use of NSAIDs and the individual risk of developing PD have generated controversial data. Discrepancies are probably the result of methodological differences ( for example: retrospective versus prospective studies) and lack of detailed analysis of the type of anti-inflammatory drug used ${ }^{13}$. Table summarizes the epidemiological studies presented in this review.

The first study investigating the possible benefits of the regular use of NSAIDs in reducing the risk of PD in humans was provided by the group of Chen and coworkers ${ }^{34}$ from the Harvard School of Public Health. This prospective analysis indicated that the risk to develop PD was $45 \%$ lower in regular users of non acetylsalicylic acid (non-ASA) NSAIDs compared with non regular users. The non-ASA NSAIDs were drugs such as diflunisal, ibuprofen, indomethacin and naproxen. A decreased risk of PD was also observed in patients who took two or more tablets of acetylsalicylic acid (ASA) per day, compared to non users, but statistical significance was not achieved for this data. Individuals who took smaller amounts of ASA or paracetamol (acetaminophen) did not show benefits ${ }^{34}$. Later, the same group of investigators reported in another large cohort of 146,565 people that ibuprofen reduced the risk of PD in men and women by $35 \%$, regardless of age and smoking status. However, no significant association was found between the regular use of ASA, other NSAIDs or acetaminophen and the risk to develop PD $^{35}$.

A surprising result was found in a case-control study performed by Etminan and Suissa ${ }^{36}$. In this study, current users of NSAIDs presented a slightly higher risk of developing PD. However, past users of NSAIDs did not show this effect. Authors encouraged more investigation to confirm the results.

A study of Hernán et al. ${ }^{37}$ from the Harvard School of Public Health showed another surprising result. They conducted a case-control study within a cohort of the world's largest computerized database, the British General Practice Research Database (GPRD), and found that the use of non-ASA NSAIDs reduces PD risk only in men but not in women. Indeed, it was reported a $20 \%$ reduction in the incidence of PD for men who regularly took non-ASA NSAIDs; and, intriguingly, a $20 \%$ increase of PD in women. This unexpected finding certainly needs further investigation.

Bower and colleagues ${ }^{38}$ found only a trend toward reduced risk of developing PD in people who took non-ASA NSAIDs or steroidal anti-inflammatory drugs, which were evaluated separately. In contrast, Ton et al..$^{39}$ in an American population-based case-control study did not find a reduction in PD risk for users of ASA nor non-ASA NSAIDs. Also, the use of ibuprofen was not associated with reduced PD risk. Therefore, no indication of protection from ASA or other NSAIDs was recognized through this study.

Bornebroek and colleagues ${ }^{40}$ obtained similar results. They did a prospective population-based cohort study among 6,512 participants of 55 years old or older, and found no association between the use of NSAIDs and risk of developing PD. In the same year, another study was published with controversial data. Wahner et al. ${ }^{41}$ studied the use of NSAIDs in another population-based case control study with 293 incident idiopathic PD cases and 286 age-, race-, and gender-matched controls from three rural California counties. Interestingly, the regular use of ASA ( $\geq 2$ pills/week for at least 1 month) was associated with a decreased risk of $\mathrm{PD}$ and this protective effect of ASA was observed only in women, especially among long term regular users ( $\geq 2$ years). A strong protective effect was also observed for regular non-ASA NSAID users, particularly for users of more than 2 years.

In a retrospective cohort study, Etminan et al. ${ }^{42}$ explored the association between NSAIDs and the risk to develop PD. Using the British Columbia Linked Health Databases (BCLHD), they created a cohort of all individuals in British Columbia who had at least a record of prescribed medication between 1997 and 2003. The results of their study did not show a protective effect of the use of NSAIDs with regard to PD risk. The authors pointed out that this study had several limitations. For example, it was not possible to control the potential risk factors for PD and they could not assess the use of over-the-counter NSAIDs as ibuprofen and ASA. In the following year, Samii and colleagues ${ }^{43}$ published a systematic review and meta-analysis of observational studies, associating NSAID use and the risk of PD. They concluded that NSAIDs as a pharmacological class do not seem to modify the risk of developing PD. However, ibuprofen alone, may have a slight protective effect. The results also suggest a slight reduction in risk of PD for male users of NSAIDs, even though the risk ratios for males and females were similar.

Another meta-analysis conducted by Gagne and Power ${ }^{44}$ suggested that there may be a protective effect of use of non-ASA NSAIDs on PD risk, consistent with a possible neuroinflammatory pathway contributing in PD pathogenesis. A $15 \%$ reduction was observed in the incidence of $\mathrm{PD}$ among non-ASA NSAIDs users, with a similar effect for ibuprofen alone, whereas the protective effect was more prominent in regular and long-term users. No protective effect was observed for ASA or acetaminophen.

The review of observational studies conducted by Rees et al. ${ }^{45}$ did not find a significant association between the risk of PD and the use of any NSAIDs or ASA. Although the data did not achieve statistical significance, the risk of developing PD was reduced by $13 \%$ in individuals exposed to non-ASA NSAIDs, and ibuprofen alone showed a $27 \%$ reduction in risk. The authors conclude that there may be a reduction in PD risk associated with the use of non-ASA 
Table. Epidemiological evidence associating the regular use of NSAIDs and the risk of developing Parkinson's disease.

\begin{tabular}{|c|c|c|c|c|c|c|c|}
\hline Authors & Type of study & Participants & PD cases & $\mathrm{RR} / \mathrm{OR}$ & $95 \% \mathrm{Cl}$ & Drugs & Results \\
\hline \multirow[t]{2}{*}{ Chen et al. ${ }^{34}$} & \multirow{2}{*}{$\begin{array}{l}\text { Prospective } \\
\text { cohort }\end{array}$} & \multirow[t]{2}{*}{142,902} & \multirow[t]{2}{*}{415} & 0.55 & $0.32-0.96$ & Non-ASA NSAIDs & \multirow{2}{*}{$\begin{array}{l}\text { Reduction in PD risk for regular users of } \\
\text { non-ASA NSAIDs }\end{array}$} \\
\hline & & & & 0.56 & $0.86-1.09$ & ASA & \\
\hline \multirow[t]{2}{*}{ Chen et al. ${ }^{35}$} & \multirow{2}{*}{$\begin{array}{l}\text { Prospective } \\
\text { cohort }\end{array}$} & \multirow[t]{2}{*}{146,565} & \multirow[t]{2}{*}{413} & 0.65 & $0.48-0.89$ & Ibuprofen & \multirow{2}{*}{$\begin{array}{l}\text { Reduction in PD risk for regular users of } \\
\text { ibuprofen. This protective effect was not } \\
\text { demonstrated for other NSAIDs, ASA or } \\
\text { acetaminophen. }\end{array}$} \\
\hline & & & & 0.78 & $0.60-1.02$ & $\begin{array}{c}\text { Non-ASA } \\
\text { NSAIDs (including ibuprofen) }\end{array}$ & \\
\hline \multirow[t]{2}{*}{$\begin{array}{l}\text { Etminan and } \\
\text { Suissa }\end{array}$} & \multirow[t]{2}{*}{ Case-control } & \multirow[t]{2}{*}{-} & \multirow[t]{2}{*}{-} & 1.49 & $1.11-2.01$ & NSAIDs & $\begin{array}{l}\text { Current users of NSAIDs have shown a } \\
\text { slightly higher risk of developing PD }\end{array}$ \\
\hline & & & & 1.18 & $0.89-1.59$ & NSAIDs & $\begin{array}{l}\text { Past users of NSAIDs did not have higher } \\
\text { risk of PD }\end{array}$ \\
\hline Hernán et al. ${ }^{37}$ & Case-control & 7,896 & 1258 & 0.93 & $0.80-1.08$ & Non-ASA NSAIDs & $\begin{array}{l}\text { Reduction in PD risk for regular users of } \\
\text { non-ASA NSAIDs in men but not in women. }\end{array}$ \\
\hline Bower et al. & Case-control & 404 & 202 & 0.50 & $0.20-1.5$ & Non-ASA NSAIDs e SAIDs & $\begin{array}{l}\text { Only a trend of reduction in PD risk for } \\
\text { users of non-ASA NSAIDs and SAIDs }\end{array}$ \\
\hline \multirow[t]{3}{*}{ Ton et al. $^{39}$} & \multirow[t]{3}{*}{ Case-control } & \multirow[t]{3}{*}{589} & \multirow[t]{3}{*}{206} & 0.90 & $0.59-1.35$ & Non-ASA NSAIDs & \multirow{3}{*}{$\begin{array}{l}\text { No association was found between use of } \\
\text { NSAIDs and reduction of PD risk. }\end{array}$} \\
\hline & & & & 0.89 & $0.60-1.32$ & Ibuprofen & \\
\hline & & & & 0.74 & $0.49-1.12$ & ASA & \\
\hline $\begin{array}{l}\text { Bornebroek et } \\
\text { al. }^{40}\end{array}$ & $\begin{array}{l}\text { Prospective } \\
\text { cohort }\end{array}$ & 6,512 & 88 & 1.50 & $0.95-2.37$ & Any NSAIDs & $\begin{array}{l}\text { No association was found between use of } \\
\text { any NSAIDs and the risk of developing PD }\end{array}$ \\
\hline \multirow[t]{4}{*}{ Wahner et al. ${ }^{41}$} & \multirow[t]{4}{*}{ Case-control } & \multirow[t]{4}{*}{579} & \multirow[t]{4}{*}{293} & 0.80 & $0.56-1.15$ & Regular ASA ( $\geq 2$ pills/week) & \multirow{4}{*}{$\begin{array}{l}\text { Regular use of ASA showed a mild } \\
\text { protective effect. The ASA effect was } \\
\text { stronger in women, especially among long } \\
\text { term regular users. A protective effect was } \\
\text { observed for regular non-ASA NSAID users } \\
\text { particularly those who reported } \geq 2 \text { years } \\
\text { of use. }\end{array}$} \\
\hline & & & & 0.52 & $0.35-0.79$ & Regular Non-ASA NSAIDs & \\
\hline & & & & 0.44 & $0.26-0.74$ & $\geq 2$ years Non-ASA NSAIDs & \\
\hline & & & & 0.51 & $0.26-1.02$ & $\geq 24$ months ASA (women) & \\
\hline $\begin{array}{l}\text { Etminan } \\
\text { et al. }\end{array}$ & $\begin{array}{l}\text { Retrospective } \\
\text { cohort }\end{array}$ & 697,078 & 5010 & 0.84 & $0.81-1.09$ & NSAIDs & $\begin{array}{l}\text { No association was found between use of } \\
\text { NSAIDs and reduction in PD risk. }\end{array}$ \\
\hline Samii et al. ${ }^{43}$ & Meta-analysis of & - & - & 0.95 & $0.80-1.12$ & NSAIDs & NSAIDs do not seem to modify the \\
\hline & $\begin{array}{l}11 \text { observational } \\
\text { studies }\end{array}$ & & & 0.91 & $0.78-1.05$ & $\begin{array}{l}\text { High-dose/long-duration } \\
\text { NSAIDs }\end{array}$ & $\begin{array}{l}\text { risk of PD. Ibuprofen may have a slight } \\
\text { protective effect. }\end{array}$ \\
\hline & & & & 1.08 & $0.93,1.26$ & ASA & \\
\hline & & & & 0.76 & $0.65,0.89$ & Ibuprofen & \\
\hline Gagne and & Meta-analysis & - & - & 0.85 & $0.77-0.94$ & Non-ASA NSAIDs & Reduction of 15\% in PD incidence \\
\hline Powe & & & & 0.71 & $0.58-0.89$ & Non-ASA NSAIDs regular users & among users of non-ASA NSAIDs with \\
\hline & & & & 0.79 & $0.59-1.07$ & $\begin{array}{c}\text { Non-ASA NSAIDs long-term } \\
\text { users }\end{array}$ & $\begin{array}{l}\text { a similar effect for ibuproten alone. In } \\
\text { contrast, no protective effect was found } \\
\text { for ASA or paracetamol. }\end{array}$ \\
\hline & & & & 0.75 & $0.64-0.89$ & Ibuprofen & \\
\hline & & & & 1.08 & $0.92-1.27$ & ASA & \\
\hline & & & & 1.06 & $0.87-1.30$ & Paracetamol & \\
\hline Rees et al. ${ }^{45}$ & Meta-analysis of & - & - & 0.87 & $0.73-1.04$ & Non-ASA NSAIDs & There were no association between \\
\hline & $\begin{array}{l}14 \text { observational } \\
\text { studies }\end{array}$ & & & 0.73 & $0.63-0.85$ & Ibuprofen & $\begin{array}{l}\text { use of any NSAIDs or ASA and the risk } \\
\text { of developing PD. Exposure to non-ASA } \\
\text { NSAIDs reduced the PD risk by } 13 \% \\
\text { without statistical significance. Ibuprofen } \\
\text { alone showed a } 27 \% \text { reduction in PD risk. }\end{array}$ \\
\hline Driver et al. ${ }^{46}$ & Case-control & 22,007 & 1181 & 1.28 & $1.05-1.56$ & Absence of non-ASA NSAIDs use & Absence of non-ASA NSAIDs use was \\
\hline & & & & 1.35 & $1.07-1.70$ & $\begin{array}{l}\text { 1-2 years of regular use of } \\
\text { non-ASA NSAID }\end{array}$ & $\begin{array}{l}\text { associated with an increased risk of PD. } \\
\text { There was an increased risk of PD in men } \\
\text { who had 1-2 years of regular non-ASA }\end{array}$ \\
\hline & & & & 1.48 & $1.05-2.09$ & $\begin{array}{l}\text { Use of non-ASA NSAIDs for } 5 \\
\text { years or more }\end{array}$ & $\begin{array}{l}\text { NSAID use. Positive association between } \\
\text { PD and use of non-ASA. This association } \\
\text { tended to disappear when analyses were } \\
\text { limited to drug use } \geq 5 \text { years before the } \\
\text { disease diagnosis. }\end{array}$ \\
\hline Manthriprag-ada & Case-control & 11,582 & 1931 & 0.97 & $0.82-1.14$ & ASA & \\
\hline & & & & 0.97 & $0.86-1.09$ & Non-ASA NSAIDs & $\begin{array}{l}\text { of PD and use of ASA or non-ASA NSAIDs } \\
\text { when used shortly before the PD onset }\end{array}$ \\
\hline Becker et al. ${ }^{48}$ & Case-control & 19,995 & 4026 & 0.94 & $0.83-1.07$ & NSAIDs long-term use & Long-term use of NSAIDs was associated \\
\hline & & & & 1.16 & $1.03-1.30$ & ASA long-term use & with a slightly lower PD risk. Use of ASA or \\
\hline & & & & 1.15 & $1.02-1.30$ & Acetaminophen long-term use & $\begin{array}{l}\text { acetaminophen was not associated with a } \\
\text { significant modification in the risk of PD. }\end{array}$ \\
\hline Gao et al. ${ }^{49}$ & Prospective & 136,197 & 291 & 0.62 & $0.42-0.93$ & Ibuprofen & Ibuprofen users have shown a \\
\hline & $\begin{array}{c}\text { cohort } \\
\text { followed by }\end{array}$ & & & 0.99 & $0.78-1.26$ & ASA & significantly lower PD risk than nonusers \\
\hline & $\begin{array}{l}\text { tollowed by } \\
\text { meta-analysis }\end{array}$ & & & 1.26 & $0.86-1.84$ & Non-ASA NSAIDs & $\begin{array}{l}\text { With an additional dose-response } \\
\text { relationship between tablets of ibuprofen }\end{array}$ \\
\hline & & & & 0.86 & $0.62-1.18$ & Paracetamol & taken per week and lower PD risk. This \\
\hline & & & & 0.73 & $0.63-0.85$ & Ibuprofen (meta-analysis) & $\begin{array}{l}\text { effect was not observed for ASA, other } \\
\text { NSAIDs or paracetamol. }\end{array}$ \\
\hline
\end{tabular}

RR: relative risk; OR: odds ratio; Cl: confidence interval; NSAIDs: non-steroidal anti-inflammatory drugs; ASA: acetylsalicylic acid; SAIDs: steroidal anti-inflammatory drugs. 
NSAIDs, particularly ibuprofen. However, the effects of other individual drugs is still uncertain. Therefore, at present, the authors do not recommend this class of drugs as primary prevention. Considering the absence of clinical trials in patients with a well-defined diagnostic of PD, there is currently no evidence for the use of NSAIDs in the treatment of PD.

The group of Driver et al. ${ }^{46}$ have conducted a case-control study to evaluate the relationship between PD and the prior use of NSAIDs in a large cohort of men. They have found no evidence for a protective effect of NSAIDs in reducing PD risk. In fact, there was an increased risk of PD in men who used ASA and non-ASA NSAID regularly for 1-2 years. These positive associations tended to disappear when analyzes were limited to NSAIDs use for 5 years or more, prior to the disease diagnosis. This suggests the results might have been influenced by the drug use concentrated in the few years prior to disease diagnosis, when people are about to manifest the first symptoms.

Similarly, in a large population-based case-control study using Danish health and pharmacy registries, Manthripragada et al. ${ }^{47}$ investigated the possible associations between the use of ASA, non-ASA NSAIDs, and acetaminophen in patients with $\mathrm{PD}$. This study found no evidence for an inverse association between PD and the use of ASA or non-ASA NSAIDs regardless of intensity of use. There was no inverse association between the use of ibuprofen or acetaminophen and PD. In conclusion, the authors highlight that their findings do not provide strong evidence for a protective effect of non-ASA and ASA drugs shortly before diagnosis of PD. As in the study of Driver et al. ${ }^{46}$, these results might have been confounded by the use of NSAIDs concentrated in the few years before the diagnosis of PD.

In accordance, the population-based case-control study performed by Becker et al. ${ }^{48}$ using the General Practice Research Database did not find a significant lower risk of developing PD associated with the use of NSAIDs, ASA or acetaminophen. Only the long-term use of NSAIDs (15 or more prescriptions) was associated with a slightly lower PD risk.

Gao et al. ${ }^{49}$ performed a prospective study with 136,197 participants of the Nurses' Health Study (NHS) and the Health Professionals Follow-up Study (HPFS) free of PD at baseline (1998 for NHS and 2000 for HPFS). The use of NSAIDs was assessed via questionnaire. The results of this prospective study were combined with those already published by prospective investigations in a meta-analysis. This study revealed that regular users of ibuprofen exhibited a significant lower risk in developing PD in comparison with non users. In addition, in this study was observed a dose-response relationship between tablets of ibuprofen taken per week and the risk of PD. Nevertheless, this protective effect was not observed in users of ASA, non-ASA NSAIDs or acetaminophen, which suggests a specific mechanism of neuroprotection for ibuprofen, not shared by other members of the class. Therefore, the authors suggest ibuprofen should be further tested as a potential neuroprotective drug in PD.

Despite several experimental and epidemiological studies have provided evidence that support the hypothesis of a protective effect of anti-inflammatory drugs in PD, many of these drugs were not rigorously tested in randomized, double-blind, placebo-controlled clinical trials, and most of the studies have generated contradictory results. This discrepancy may be the result of peculiar characteristics of each drug, which are very different with regards to their chemical structure and their mechanisms of action unrelated to COX inhibition $^{29}$. Therefore, NSAIDs should be individually assessed concerning their neuroprotective properties in $\mathrm{PD}^{28}$.

Several researchers believe that in the coming years new approaches will support the current therapy based on dopamine replacement for PD through early diagnosis and treatment with neuroprotective drugs. There is still a lot to be explored especially regarding non-classical mechanisms of action of NSAIDs ${ }^{29}$. Ibuprofen should be further explored by researchers and health professionals, because it is the NSAID which promotes the greatest reduction of the risk in developing PD in many epidemiological studies.

\section{CONCLUSION AND FUTURE DIRECTION}

There is the possibility that NSAIDs may be used for the prevention of neurodegenerative diseases in the future instead of being treatment for them, because it is probable that these drugs are ineffective when neuronal degeneration is already in an advanced stage. Thus, pharmacological intervention should be started in the pre-symptomatic period (prodromal phase) in order to be effective ${ }^{29}$. Of course, this would be possible by improving the early diagnosis of the disease. However, it is important to consider that long-term treatment with NSAIDs has a number of adverse side-effects, particularly gastrointestinal lesions, which could constitute a limitation to their prolonged use ${ }^{6}$.

Finally, some considerations are important for future experimental designs in this research area. In preclinical studies, it is relevant to compare the neuroprotective and behavioral effects of anti-inflammatory drugs in treatment approaches before and after lesions with dopaminergic neurotoxins. These experimental designs would contribute to confirm if these drugs are helpful in preventative and/or therapeutic regimens, and the possible contribution of the inflammatory process in the development and progression of PD. Concerning epidemiological studies, prospective and retrospective cohorts and casecontrol studies should also evaluate NSAIDs in isolation, and not as a class; and the several confounding variables such as age, gender, smoking and coffee habits should be corrected. Epidemiological studies could also help to clarify the possible relationship between acute and chronic 
inflammatory and infectious diseases, and the development of PD later in life. With regard to clinical trials, it is important to stratify the patients with PD according to the disease stage and severity, because such factors may influence the treatment response. In conclusion, the study of anti-inflammatory drugs is an important starting point that, for the first time, can lead us to the development of agents able to modify the course of PD.

\section{References}

1. Reichmann H, Schneider C, Löhle M. Non-motor features of Parkinson's disease: depression and dementia. Parkinsonism Relat Disord. 2009;15 Suppl 3:S87-92. http://dx.doi.org/10.1016/S1353-8020(09)70789-8

2. Barbosa MT, Caramelli P, Maia DP, Cunningham MC, Guerra HL, Lima-Costa MF et al. Parkinsonism and Parkinson's disease in the elderly: a community-based survey in Brazil (the Bambuí study). Mov Disord. 2006;21:800-8. http://dx.doi.org/10.1002/mds.20806

3. Munhoz RP, Werneck LC, Teive HA. The differential diagnoses of parkinsonism: findings from a cohort of 1528 patients and a 10 years comparison in tertiary movement disorders clinics. Clin Neurol Neurosurg. 2010;112:431-5. http://dx.doi.org/10.1016/j.clineuro.2010.03.003

4. Dauer W, Przedborski S. Parkinson's disease: mechanisms and models. Neuron. 2003:39(6):889-909. http://dx.doi.org/10.1016/S0896-6273(03)00568-3

5. Long-Smith CM, Sullivan AM, Nolan YM. The influence of microglia on the pathogenesis of Parkinson's disease. Prog Neurobiol. 2009;89(3):277-87. http://dx.doi.org/10.1016/j.pneurobio.2009.08.001

6. Hirsch EC, Hunot S. Neuroinflammation in Parkinson's disease: a target for neuroprotection? Lancet Neurol. 2009;8(4):382-97. http://dx.doi.org/10.1016/S1474-4422(09)70062-6

7. Singh N, Pillay V, Choonara YE. Advances in the treatment of Parkinson's disease. Prog Neurobiol. 2007;81 (1):29-44. http://dx.doi.org/10.1016/j.pneurobio.2006.11.009

8. Hirsch EC, Hunot S, Hartmann A. Neuroinflammatory processes in Parkinson's disease. Parkinsonism Relat Disord. 2005;11 Suppl 1:S9-15. http://dx.doi.org/10.1016/j.parkreldis.2004.10.013

9. Sanders LH, Greenamyre JT. Oxidative damage to macromolecules in human Parkinson disease and the rotenone model. Free Radic Biol Med. 2013;62:111-20. http://dx.doi.org/10.1016/j.freeradbiomed.2013.01.003

10. Tansey MG, Goldberg MS. Neuroinflammation in Parkinson's disease: its role in neuronal death and implications for therapeutic intervention. Neurobiol Dis. 2010;37(3):510-8. http://dx.doi.org/10.1016/j.nbd.2009.11.004

11. McGeer PL, Itagaki S, Boyes BE, McGeer EG. Reactive microglia are positive for HLA-DR in the substantia nigra of Parkinson's and Alzheimer's disease brains. Neurology. 1988;38(8):1285-91. http://dx.doi.org/10.1212/WNL.38.8.1285

12. Brochard V, Combadière B, Prigent A, Laouar Y, Perrin A, Beray-Berthat $V$ et al. Infiltration of CD4+ lymphocytes into the brain contributes to neurodegeneration in a mouse model of Parkinson disease. J Clin Invest. 2009;119(1):182-92. http://dx.doi.org/10.1172/JCl36470

13. Hirsch EC, Vyas $S$, Hunot S. Neuroinflammation in Parkinson's disease. Parkinsonism Relat Disord. 2012;18 Suppl 1:S210-2. http://dx.doi.org/10.1016/S1353-8020(11)70065-7

14. Hirsch EC, Jenner P, Przedborski S. Pathogenesis of Parkinson's disease. Mov Disord. 2013;28(1):24-30. http://dx.doi.org/10.1002/mds.25032

15. Witte ME, Geurts JJG, Vries HE, Valk P, Horssen J. Mitochondrial dysfunction: a potential link between neuroinflammation and neurodegeneration? Mitochondrion. 2010;10(5):411-8. http://dx.doi.org/10.1016/j.mito.2010.05.014
16. Politis M, Su P, Piccini P. Imaging of microglia in patients with neurodegenerative disorders. Front Pharmacol. 2012;3:96. http://dx.doi.org/10.3389/fphar.2012.00096

17. Ghosh A, Roy A, Liu X, Kordower JH, Mufso EJ, Hartley DM et al. Selective inhibition of NF-kappaB activation prevents dopaminergic neuronal loss in a mouse model of Parkinson's disease. Proc Natl Acad Sci USA. 2007;104(47):18754-9. http://dx.doi.org/10.1073/pnas.0704908104

18. Mondal S, Roy A, Jana A, Ghosh S, Kordower JH, Pahan $\mathrm{K}$. Testing NF-kB-based therapy in hemiparkinsonian monkeys. J Neuroimmune Pharmacol. 2012;7(3):544-56. http://dx.doi.org/10.1007/s11481-012-9377-9

19. Wilms H, Rosenstiel P, Sievers J, Deuschl G, Zecca L, Lucius R. Activation of microglia by human neuromelanin is NF-kappaB dependent and involves p38 mitogen-activated protein kinase: implications for Parkinson’s disease. FASEB J. 2003;17(3):500-2. http://dx.doi.org/10.1096/fj.02-0314fje

20. Zhang F, Qian L, Flood PM, Shi JS, Hong JS, Gao HM. Inhibition of lkappaB kinase-beta protects dopamine neurons against lipopolysaccharide-induced neurotoxicity. JPET; 2010;333(3):822-33. http://dx.doi.org/10.1124/jpet.110.165829

21. Lima MMS, Reksidler AB, Zanata SM, Machado HB, Tufik S, Vital MA. Different parkinsonism models produce a time-dependent induction of COX-2 in the substantia nigra of rats. Brain Res. 2006;1101(1):117-25. http://dx.doi.org/10.1016/j.brainres.2006.05.016

22. Hald A, Lotharius J. Oxidative stress and inflammation in Parkinson's disease: Is there a causal link? Exp Neurol. 2005;193(2):279-90. http://dx.doi.org/10.1016/j.expneurol.2005.01.013

23. Tansey MG, McCoy MK, Frank-Cannon TC. Neuroinflammatory mechanisms in Parkinson's disease: potential environmental triggers, pathways, and targets for early therapeutic intervention. Exp Neurol. 2007:208(1):1-25. http://dx.doi.org/10.1016/j.expneurol.2007.07.004

24. Collins LM, Toulouse A, Connor TJ, Nolan YM. Contributions of central and systemic inflammation to the pathophysiology of Parkinson's disease. Neuropharmacology. 2012;62(7):2154-68. http://dx.doi.org/10.1016/j.neuropharm.2012.01.028

25. Castaño A, Herrera AJ, Cano J, Machado A. The degenerative effect of a single intranigral injection of LPS on the dopaminergic system is prevented by dexamethasone, and not mimicked by rh-TNF-alfa, IL-1 beta and IFN-gamma.J Neurochem. 2002;81(1):150-7. http://dx.doi.org/10.1046/j.1471-4159.2002.00799.x

26. Kurkowska-Jastrzebska I, Litwin T, Joniec I, Ciesielska A, Przbylkowski A, Czlonkowski A et al. Dexamethasone protects against dopaminergic neurons damage in a mouse model of Parkinson's disease. Int Immunopharmacol. 2004;4(10-11):1307-18. http://dx.doi.org/10.1016/j.intimp.2004.05.006

27. Pott Godoy MC, Tarelli R, Ferrari CC, Sarchi MI, Pitossi FJ. Central and systemic IL-1 exacerbates neurodegeneration and motor symptoms in a model of Parkinson's disease. Brain. 2008;131(Pt 7):1880-94. http://dx.doi.org/10.1093/brain/awn101

28. Asanuma M, Miyazaki I. Common anti-inflammatory drugs are potentially therapeutic for Parkinson's disease? Exp Neurol. 2007;206(2):172-8. http://dx.doi.org/10.1016/j.expneurol.2007.05.006 
29. Esposito E, Di Matteo V, Benigno A, Pierucci M, Crescimanno G, Di Giovanni G. Non-steroidal anti-inflammatory drugs in Parkinson's disease. Exp Neurol. 2007;205(2):295-312. http://dx.doi.org/10.1016/j.expneurol.2007.02.008

30. Reksidler AB, Lima MM, Zanata SM, Machado HB, Cunha C, Andreatini $R$ et al. The COX-2 inhibitor parecoxib produces neuroprotective effects in MPTP-lesioned rats. Eur J Pharmacol. 2007;560(2-3):163-75. http://dx.doi.org/10.1016/j.ejphar.2006.12.032

31. Zaminelli T, Gradowski RW, Bassani TB, et al. Antidepressant and Antioxidative Effect of Ibuprofen in the Rotenone Model of Parkinson's Disease. Neurotox Res. 2014;25(3). http://dx.doi.org/10.1007/s12640-014-9467-y.

32. Swiątkiewicz M, Zaremba M, Joniec I, Członkowski A, KurkowskaJastrzębska I. Potential neuroprotective effect of ibuprofen, insights from the mice model of Parkinson's disease. Pharmacol Rep. 2013;65(5):1227-36. http://dx.doi.org/10.1016/S1734-1140(13)71480-4

33. Barbiero JK, Santiago RM, Lima MM, Ariza D, Morais LH, Andreatini R et al. Acute but not chronic administration of pioglitazone promoted behavioral and neurochemical protective effects in the MPTP model of Parkinson's disease. Behav Brain Res. 2011;216(1):186-92. http://dx.doi.org/10.1016/j.bbr.2010.07.033

34. Chen H, Zhang SM, Hernán MA, Schwarzchild MA, Willett WC, Colditz GA et al. Nonsteroidal anti-inflammatory drugs and the risk of Parkinson disease. Arch Neurol. 2003;60(8):1059-64. http://dx.doi.org/10.1001/archneur.60.8.1059

35. Chen H, Jacobs E, Schwarzschild MA, McCullough M, CAlle EE, Thun MJ et al. Nonsteroidal antiinflammatory drug use and the risk for Parkinson's disease. Ann Neurol. 2005;58(6):963-7. http://dx.doi.org/10.1002/ana.20682

36. Etminan M, Suissa S. NSAID use and the risk of Parkinson's disease. Curr Drug Saf. 2006;1(3):223-5. http://dx.doi.org/10.2174/157488606777934404

37. Hernán MA, Logroscino G, García Rodríguez LA. Nonsteroidal anti-inflammatory drugs and the incidence of Parkinson disease. Neurology. 2006;66(7):1097-9. http://dx.doi.org/10.1212/01.wnl.0000204446.82823.28

38. Bower JH, Maraganore DM, Peterson BJ, Ahlskog JE, Rocca WA. Immunologic diseases, anti-inflammatory drugs, and Parkinson disease: a case-control study. Neurology. 2006;67(3):494-6. http://dx.doi.org/10.1212/01.wnl.0000227906.99570.cc

39. Ton TG, Heckbert SR, Longstreth Jr WT, Rossing MA, Kukul WA, Franklin GM et al. Nonsteroidal anti-inflammatory drugs and risk of Parkinson's disease. Mov Disord. 2006;21(7):964-9. http://dx.doi.org/10.1002/mds.20856

40. Bornebroek M, Lau LM, Haag MD, Koudstaal PJ, Hofma A, Stricker $\mathrm{BH}$ et al. Nonsteroidal anti-inflammatory drugs and the risk of Parkinson disease. Neuroepidemiology. 2007;28(4):193-6. http://dx.doi.org/10.1159/000108110

41. Wahner AD, Bronstein JM, Bordelon YM, Ritz B. Nonsteroidal anti-inflammatory drugs may protect against Parkinson disease. Neurology. 2007;69(19):1836-42. http://dx.doi.org/10.1212/01.wnl.0000279519.99344.ad

42. Etminan M, Carleton BC, Samii A. Non-steroidal antiinflammatory drug use and the risk of Parkinson disease: a retrospective cohort study. J Clin Neurosci. 2008;15(5):576-7. http://dx.doi.org/10.1016/j.jocn.2007.02.095

43. Samii A, Etminan M, Wiens MO, Jafari S. NSAID use and the risk of Parkinson's disease: systematic review and meta-analysis of observational studies. Drugs Aging. 2009;26(9):769-79. http://dx.doi.org/10.2165/11316780-000000000-00000

44. Gagne JJ, Power MC. Anti-inflammatory drugs and risk of Parkinson disease: a meta-analysis. Neurology. 2010;74(12):995-1002. http://dx.doi.org/10.1212/WNL.0b013e3181d5a4a3

45. Rees K, Stowe R, Patel S, Ives N Breen K, Carke CE et al. Non-steroidal anti-inflammatory drugs as disease-modifying agents for Parkinson's disease: evidence from observational studies. Cochrane Database Syst Rev. 2011;(11):CD008454. http://dx.doi.org/10.1002/14651858.CD008454.pub2.

46. Driver JA, Logroscino G, Lu L, Michael Gaziano J, Kurth T. Use of non-steroidal anti-inflammatory drugs and risk of Parkinson's disease: nested case-control study. BMJ. 2011;342:d198. http://dx.doi.org/10.1136/bmj.d198

47. Manthripragada AD, Schernhammer ES, Qiu J, Friis S, Wermuth L, Olsen JH et al. Non-steroidal anti-inflammatory drug use and the risk of Parkinson's disease. Neuroepidemiology. 2011;36(3):155-61. http://dx.doi.org/10.1159/000325653

48. Becker C, Jick SS, Meier CR. NSAID use and risk of Parkinson disease: a population-based case-control study. Eur J Neurol. 2011;18(11):1336-42. http://dx.doi.org/10.1111/j.1468-1331.2011.03399.x

49. Gao X, Chen H, Schwarzschild MA, Ascherio A. Use of ibuprofen and risk of Parkinson disease. Neurology. 2011;76(10):863-9. http://dx.doi.org/10.1212/WNL.0b013e31820f2d79 